\title{
KARAKTERISTIK FISIKOKIMIA SELAI KULIT BUAH NAGA (Hylocereus polyrhizus) DENGAN PENAMBAHAN VARIASI KONSENTRASI BUAH NANAS (Ananas comosus L.)
}

Physicochemical Characteristic of Dragon Fruit Peels (Hylocereus polyrhizus) Jam with the Addition of Variation Concentration of Pineapple Fruit (Ananas comosus L.)

\author{
Pratiwi Jati Palupi $^{1 * *}$, Retno Prasetia ${ }^{1)}$, Muh. Doddy Pratama ${ }^{1)}$, Indah Sriwahyuni ${ }^{1)}$ \\ ${ }^{1)}$ Program Studi Teknologi Industri Pertanian, Fakultas Teknik, Universitas Nahdlatul Ulama \\ Kalimantan Timur \\ Jalan KH. Harun Nafsi Kec. Loa Janan Ilir Samarinda, Kalimantan Timur 756123, Indonesia \\ *Korespondensi Penulis: pratiwi.jp@gmail.com
}

\begin{abstract}
Dragon fruit peels (Hylocereus polyrhizus) are generally only considered trash by the public because they are considered useless, even though dragon fruit peels still contain useful nutrients. Dragon fruit skin can be used as food, one of which is a jam. The addition of pineapple fruit variations to dragon fruit peel jam as a flavor enhancer and natural fragrance to reduce the use of sugar in jam and the aroma of pineapple fruit can mask the distinctive aroma of dragon fruit which is less desirable. The purpose of this study was to determine the appropriate concentration variations in the manufacture of dragon fruit peel jam with the addition of pineapple, which consumers liked. This study used a completely randomized design with six (6) treatments and two (2) replications. Dragon fruit peel jams analyzed by chemical tests included moisture content, sugar level, and pH, while organoleptic test included color, texture, taste, aroma, and a total of 30 untrained panelists. Observation data were processed using ANOVA $(\alpha=5 \%)$ and further tested using the honest significant difference test (BNJ) $(\alpha=5 \%)$. The results showed that the pineapple's addition to dragon fruit peel jam had a very significant effect on the panelists' preference for aroma and taste, but not significantly different from the color, texture, and chemical characteristics of jam. The N6 treatment (dragon fruit peel $250 \mathrm{~g}$ : pineapple fruit $250 \mathrm{~g}$ ) was the best jam, based on chemical characteristics ( $\mathrm{pH}$ content of 3.52, moisture content of $18.65 \%$, sugar level of 53.30\%) and preferable in organoleptic characteristics (2.97 of color, 2.97 of texture, 2.97 of flavor, 3.00 of taste).
\end{abstract}

Keywords: agricultural waste, dragon fruit peel, jam, pineapple

\section{PENDAHULUAN}

Buah naga (Hylocereus polyrhizus) umumnya dimakan daging buahnya, sedangkan kulitnya akan dibuang. Kulit buah dianggap sebagai bahan yang tidak berguna dan cenderung dibuang karena rasanya yang tidak enak, pahit, asam, dan hambar. Kulit buah yang memiliki nilai gizi yang tidak kalah dengan daging buahnya yaitu kulit buah naga. Kulit buah naga per $100 \mathrm{~g}$ mengandung protein $0,53 \mathrm{~g}$; lemak 2,00 g; serat 0,71 g; vitamin C sebesar 9,40 $\mathrm{mg}$; karbohidrat $11,5 \mathrm{~g}$; dan fosfor $8,70 \mathrm{mg}$ (Taiwan Food Industry Development and Research Authorities, 2005), serta keunggulan kulit buah naga lainnya yaitu kaya polifenol dan merupakan sumber antioksidan (Wu et al., 2006).

Pengenalan dan pemanfaatan kulit buah naga sudah diketahui secara umum oleh masyarakat, salah satunya adalah pembuatan selai. Selai kulit buah naga memiliki aroma khas buah naga yang kurang diminati dan warna selai juga kurang menarik yaitu keunguan gelap akibat proses karamelisasi gula (Huriah et al., 2019).

Berdasarkan permasalahan tersebut perlu adanya bahan tambahan yang bisa meningkatkan aroma dan warna selai kulit buah naga tanpa mengurangi karakteristik selai tersebut serta mengurangi penggunaan gula. Salah satunya dengan mencari buah 
yang manis dan memiliki aroma khas seperti buah nanas.

Penambahan buah nanas (Ananas comosus L.) pada pembuatan selai kulit buah naga dimaksudkan untuk memperbaiki cita rasa dan nilai gizi produk. Nanas memiliki kombinasi rasa yang baik yaitu manis, masam, dan segar serta memiliki kandungan gizi yang lengkap. Dalam $100 \mathrm{~g}$ buah nanas terkandung 13,7 g karbohidrat; $0,4 \mathrm{~g}$ protein; $0,2 \mathrm{~g}$ lemak; $24 \mathrm{mg}$ vitamin $\mathrm{C}$; $16 \mathrm{mg}$ kalsium; $11 \mathrm{mg}$ fosfor; $0,9 \mathrm{mg}$ besi; dan 0,08 mg vitamin B1 (Departemen Kesehatan, 1996). Namun konsentrasi buah nanas yang tepat untuk menghasilkan selai kulit buah naga dengan karakteristik terbaik dan disukai konsumen belum dilakukan sebelumnya. Oleh karena itu, penelitian ini dilakukan untuk mengetahui variasi konsentrasi yang tepat dalam pembuatan selai kulit buah naga dengan penambahan buah nanas sehingga diketahui karakteristik kimia dan organoleptik selai kulit buah naga yang disukai panelis.

\section{METODE PENELITIAN}

\section{Alat dan Bahan}

Peralatan yang digunakan dalam penelitian ini yaitu blender (Oxone OX864N), pisau (Relance), panci (Jawa), kompor gas (Todachi), thermometer alkohol, refractometer (Kenko), oven (Binder), $\mathrm{pH}$ meter (Istek Neomet), neraca analitik (Ohaus Pioneer). Bahan-bahan yang digunakan dalam penelitian ini meliputi kulit buah naga merah yang didapat dari pedagang jus buah Samarinda, daging buah nanas, gula pasir (Gulaku), air, dan asam sitrat (Cap Merak). Proses analisis kimia membutuhkan pelarut aquades dan metanol 95\%.

\section{Tahapan Penelitian}

Pembuatan Selai Kulit Buah Naga dengan Penambahan Buah Nanas

Kulit buah naga merah dipilih yang masih segar (tidak busuk dan berubah warna) dan dicuci bersih dari kotoran yang menempel. Selanjutnya blender (tombol 1) semua bahan yang telah ditimbang sesuai perlakuan (Tabel 1) selama 2 menit dan dipanaskan pada suhu $70-80^{\circ} \mathrm{C}$ selama 25 menit dalam panci sambil terus diaduk supaya panasnya merata. Selai kemudian disimpan ke dalam toples kaca dan didinginkan di suhu ruang selama 60 menit selanjutnya ditutup rapat.

\section{Rancangan Percobaan}

Penelitian ini menggunakan rancangan acak lengkap (RAL) dengan enam (6) perlakukan dan dua (2) pengulangan pada masing-masing perlakuan. Formulasi selai buah naga yaitu N1 (kulit buah naga $500 \mathrm{~g}$ ), N2 (kulit buah naga $450 \mathrm{~g}$ dan $50 \mathrm{~g}$ buah nanas), N3 (kulit buah naga $400 \mathrm{~g}$ dan $100 \mathrm{~g}$ buah nanas), N4 (kulit buah naga $350 \mathrm{~g}$ dan $150 \mathrm{~g}$ buah nanas), N5 (kulit buah naga $300 \mathrm{~g}$ dan 200 $\mathrm{g}$ buah nanas) dan N6 (kulit buah naga 250 $\mathrm{g}$ dan $250 \mathrm{~g}$ buah nanas). Formulasi selai kulit buah naga merah dengan penambahan variasi konsentrasi buah nanas ditunjukkan pada Tabel 1. Data hasil pengamatan diolah menggunakan ANOVA $(\alpha=5 \%)$ dan diuji lanjut menggunakan uji beda nyata jujur (BNJ) $(\alpha=5 \%)$.

Tabel 1. Formulasi selai kulit buah naga merah dengan penambahan variasi konsentrasi buah nanas

\begin{tabular}{cccccc}
\hline Perlakuan & $\begin{array}{c}\text { Kulit } \\
\text { buah } \\
\text { naga }(\mathrm{g})\end{array}$ & $\begin{array}{c}\text { Buah } \\
\text { nanas } \\
(\mathrm{g})\end{array}$ & $\begin{array}{c}\text { Gula } \\
(\mathrm{g})\end{array}$ & $\begin{array}{c}\text { Air } \\
(\mathrm{mL})\end{array}$ & $\begin{array}{c}\text { Asam } \\
\text { sitrat } \\
(\mathrm{g})\end{array}$ \\
\hline N1 & 500 & 0 & 200 & 100 & 2 \\
N2 & 450 & 50 & 200 & 100 & 2 \\
N3 & 400 & 100 & 200 & 100 & 2 \\
N4 & 350 & 150 & 200 & 100 & 2 \\
N5 & 300 & 200 & 200 & 100 & 2 \\
N6 & 250 & 250 & 200 & 100 & 2 \\
\hline
\end{tabular}

Keterangan: Berat total dari bahan utama (kulit buah naga merah dan buah nanas) adalah $500 \mathrm{~g}$

\section{Metode Analisis}

Pembuatan selai kulit buah naga merah dengan penambahan variasi buah nanas merujuk pada metode yang dilakukan 
oleh Hardita et al. (2016) yang telah dimodifikasi. Produk selai selanjutnya dianalisis secara kimia dan organoleptik. Uji kimia meliputi kadar air, pH, dan kadar gula. Uji kadar air dilakukan dengan metode gravimetri atau menggunakan oven bersuhu $105^{\circ} \mathrm{C}$ (Ramadhani et al., 2017). Uji kadar gula menggunakan alat refractometer (Arsyad, 2018). Uji pH menggunakan alat $\mathrm{pH}$ meter dengan sampel $1 \mathrm{~g}$ ditambahkan aquades sebanyak $10 \mathrm{~mL}$ (Gultom et al., 2018).

Pengujian organoleptik dilakukan secara hedonik meliputi warna, tekstur, rasa, dan aroma dengan jumlah panelis tidak terlatih sebanyak 30 orang berusia 23-72 tahun. Panelis diminta memberikan skor 13 dengan rincian 1 (kurang suka), 2 (suka), 3 (sangat suka).

\section{HASIL DAN PEMBAHASAN}

\section{Karakteristik Organoleptik Selai Kulit Buah Naga dengan Penambahan Buah Nanas}

Karakteristik organoleptik selai yang diamati meliputi warna, tekstur, rasa, dan aroma. Perlakuan selai kulit buah naga dengan penambahan variasi konsentrasi buah nanas berpengaruh sangat nyata terhadap warna, tekstur, rasa, dan aroma selai. Nilai skor uji organoleptik selai kulit buah naga dengan penambahan variasi buah nanas disajikan pada Tabel 2.

Tabel 2. Nilai skor uji organoleptik pada selai kulit buah naga dengan penambahan buah nanas

\begin{tabular}{ccccc}
\hline \multirow{2}{*}{ Perlakuan } & \multicolumn{4}{c}{ Nilai skor uji organoleptik } \\
\cline { 2 - 5 } & Warna & Tekstur & Rasa & Aroma \\
\hline N1 & $2,00^{\mathrm{a}}$ & $2,73^{\mathrm{a}}$ & $1,67^{\mathrm{a}}$ & $1,50^{\mathrm{a}}$ \\
N2 & $2,80^{\mathrm{b}}$ & $2,97^{\mathrm{a}}$ & $2,20^{\mathrm{b}}$ & $2,10^{\mathrm{b}}$ \\
N3 & $3,00^{\mathrm{b}}$ & $2,97^{\mathrm{a}}$ & $2,57^{\mathrm{bc}}$ & $2,77^{\mathrm{c}}$ \\
N4 & $2,97^{\mathrm{b}}$ & $2,97^{\mathrm{a}}$ & $2,77^{\mathrm{c}}$ & $2,80^{\mathrm{c}}$ \\
N5 & $2,93^{\mathrm{b}}$ & $2,97^{\mathrm{a}}$ & $2,67^{\mathrm{c}}$ & $2,90^{\mathrm{c}}$ \\
N6 & $2,97^{\mathrm{b}}$ & $2,97^{\mathrm{a}}$ & $2,97^{\mathrm{c}}$ & $3,00^{\mathrm{c}}$ \\
\hline
\end{tabular}

Keterangan: Nilai yang diikuti oleh huruf yang sama pada kolom yang sama tidak berbeda nyata pada taraf uji BNJ 0,05
Warna (Lightness) Selai Kulit Buah Naga

Setiap panelis memiliki perbedaan persepsi terhadap kesukaan warna. Warna pada makanan yang ditampilkan memengaruhi persepsi panelis tentang rasa dan tingkat kemanisannya (Huriah et al., 2019).

Berdasarkan Tabel 2, warna selai kulit buah naga terbaik (skor tertinggi) diperoleh pada perlakuan N3 (selai dengan perbandingan kulit buah naga $400 \mathrm{~g}$ dan 100 $\mathrm{g}$ buah nanas). Hal ini dikarenakan warna pada perlakuan N3 menghasilkan lightness terbaik sehingga banyak panelis tertarik terhadap warna tersebut. Berdasarkan Uji BNJ 5\% yang dilakukan, perlakuan N3 tidak berbeda nyata terhadap perlakuan $\mathrm{N} 2$, N4, N5, dan N6, berbeda halnya terhadap N1 yang memberikan hasil berbeda sangat nyata (Tabel 2). N1 merupakan perlakuan tanpa penambahan buah nanas, sehingga dapat dikatakan adanya penambahan buah nanas pada selai kulit buah naga dapat meningkatkan lightness warna dari selai tersebut (Gambar 1).

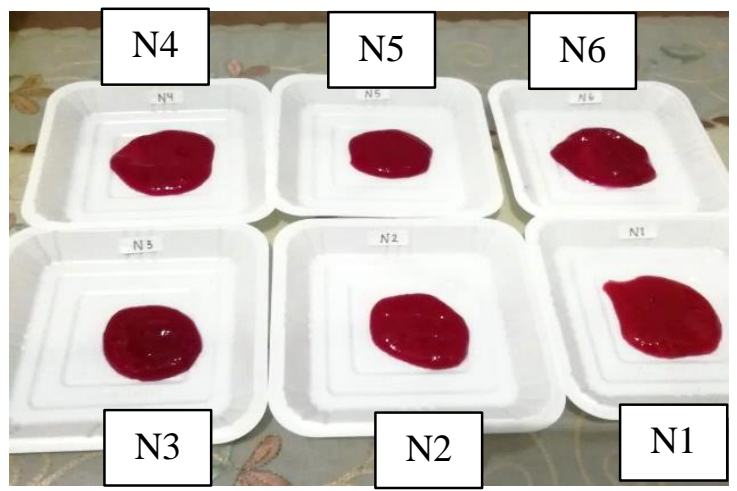

Gambar 1. Warna selai kulit buah naga dengan penambahan variasi konsentrasi buah nanas, yaitu dengan variasi kulit buah naga $500 \mathrm{~g}(\mathrm{~N} 1)$, kulit buah naga $450 \mathrm{~g}$ dan $50 \mathrm{~g}$ buah nanas (N2), kulit buah naga $400 \mathrm{~g}$ dan $100 \mathrm{~g}$ buah nanas (N3), kulit buah naga $350 \mathrm{~g}$ dan $150 \mathrm{~g}$ buah nanas (N4), kulit buah naga $300 \mathrm{~g}$ dan $200 \mathrm{~g}$ buah nanas (N5), dan kulit buah naga $250 \mathrm{~g}$ dan $250 \mathrm{~g}$ buah nanas 


\section{Tekstur Selai Kulit Buah Naga}

Penilaian tekstur suatu produk makanan merupakan penilaian berdasarkan indra peraba, yang menunjukkan tingkat kasar, halus, keras, atau lembek (Waysima et al., 2010). Menurut Winarno (2004), tekstur yang semakin kental dari suatu bahan menyebabkan penerimaan terhadap rasa dan bau semakin berkurang. Selai yang baik adalah selai yang memiliki kelunakan yang tidak terlalu kental dan tidak terlalu encer karena selai yang terlalu kental atau terlalu encer akan sulit dioleskan. Hal ini dapat mempengaruhi peneriman panelis terhadap produk selai yang dihasilkan (Syaifuddin et al., 2019).

Berdasarkan Tabel 2, skor tekstur tertinggi diperoleh pada perlakukan N2, N3, N4, N5, dan N6 dengan skor yang sama yaitu 2,97 (suka-sangat suka). Berdasarkan uji BNJ 5\%, perlakuan N1 pengaruhnya tidak berbeda nyata terhadap perlakuan lainnya (Tabel 2). Hasil ini menunjukkan bahwa dengan ataupun tanpa penambahan buah nanas, tekstur dari selai buah naga tidak memiliki perbedaan baik pada perlakuan N1 hingga N6. Adapun tekstur selai yang diperoleh yaitu tidak kental dan tidak encer sesuai dengan SNI-01-37462008.

\section{Rasa Selai Kulit Buah Naga}

Berdasarkan Tabel 2, skor tertinggi untuk rasa selai kulit buah naga diperoleh pada perlakuan N6 (selai dari kulit buah naga $250 \mathrm{~g}$ dan $250 \mathrm{~g}$ buah nanas) yaitu 2,97 (suka - sangat suka) dengan pengaruh tidak berbeda nyata terhadap perlakuan N3, N4, dan N5, tetapi berbeda sangat nyata terhadap perlakuan $\mathrm{N} 1$ dan $\mathrm{N} 2$. Hal ini menunjukkan bahwa semakin banyak buah nanas yang ditambahkan, semakin terasa asam selai yang dihasilkan sehingga muncul kombinasi rasa asam manis yang disukai oleh panelis (perlakuan N3 hingga N6). Rasa asam pada nanas disebabkan oleh asam yang terkandung dalam buah nanas yaitu asam sitrat, asam malat, dan asam oksalat, namun asam yang paling dominan yakni asam sitrat $78 \%$ dari total asam (Irfandi, 2005).

Pada perlakukan N2 rasa kurang disukai panelis dikarenakan jumlah nanas yang ditambahkan sangat sedikit sehingga kurang meningkatkan rasa selai kulit buah naga. Menurut Kumalasari (2015), buah nanas memiliki kombinasi rasa yang baik yaitu asam, manis, dan segar sehingga dapat meningkatkan rasa dari suatu makanan. Penambahan konsentrasi nanas yang berbeda meningkatkan rasa selai kulit buah naga. Peningkatan konsentrasi nanas memberikan hasil yang signifikan. Konsentrasi nanas $250 \mathrm{~g}$ pada selai kulit buah naga disukai panelis karena memiliki kombinasi rasa asam manis.

\section{Aroma Selai Kulit Buah Naga}

Aroma merupakan bau khas yang dihasilkan oleh suatu makanan dan dinilai subjektif oleh indra penciuman (Herlina et al., 2020). Aroma yaitu bau yang sukar diukur sehingga menimbulkan pendapat yang berlainan dalam menilai kualitas aromanya. Perbedaan pendapat ini disebabkan karena setiap orang memiliki perbedaan penciuman, meskipun mereka dapat membedakan aroma namun setiap orang mempunyai kesukaan yang berbeda (Santoso \& Fibrianto, 2017).

Berdasarkan data pada Tabel 2, aroma selai terbaik (skor tertinggi) diperoleh pada perlakuan N6. Hal ini dikarenakan aroma pada perlakuan N6 menghasilkan kombinasi aroma wangi dari kulit buah naga dan buah nanas sehingga banyak panelis suka terhadap aroma tersebut.

Berdasarkan uji BNJ 5\% yang dilakukan, perlakuan N6 tidak berbeda nyata terhadap perlakuan $\mathrm{N} 3, \mathrm{~N} 4$, dan $\mathrm{N} 5$, berbeda halnya terhadap N1 dan N2 yang memberikan hasil berbeda sangat nyata (Tabel 2). N1 merupakan perlakuan tanpa penambahan buah nanas dan N2 perlakukan dengan penambahan sedikit buah nanas (50 g), sehingga dapat dikatakan adanya variasi penambahan buah nanas pada selai kulit 
buah naga dapat meningkatkan aroma dari selai kulit buah naga. Buah nanas memiliki aroma yang sangat kuat karena memiliki senyawa volatil yaitu senyawa metil-3hidroksibutirat, metil-3-hidroksiheksanoat, dimetil malonat, dan asetoksiaseton. (Kumalasari et al., 2015).

\section{Karakteristik Kimia Selai Kulit Buah Naga dengan Penambahan Buah Nanas Kadar Air Selai Kulit Buah Naga}

Kadar air dalam bahan pangan ikut menentukan kesegaran dan daya awet bahan pangan tersebut. Keberadaan air pada selai kulit buah naga dengan penambahan buah nanas sebagai penentu mutu organoleptik.

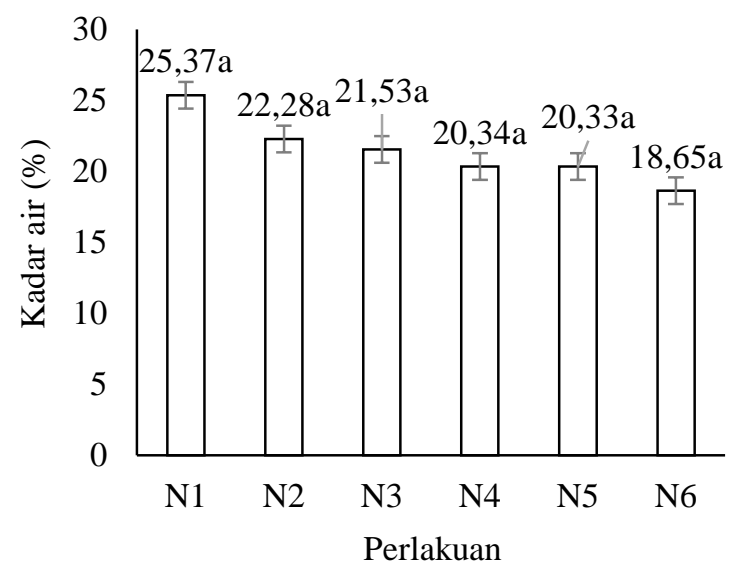

Gambar 2. Kadar air selai kulit buah naga dengan penambahan buah nanas, dengan variasi kulit buah naga $500 \mathrm{~g}(\mathrm{~N} 1)$, kulit buah naga $450 \mathrm{~g}$ dan $50 \mathrm{~g}$ buah nanas (N2), kulit buah naga $400 \mathrm{~g}$ dan $100 \mathrm{~g}$ buah nanas (N3), kulit buah naga $350 \mathrm{~g}$ dan $150 \mathrm{~g}$ buah nanas (N4), kulit buah naga $300 \mathrm{~g}$ dan $200 \mathrm{~g}$ buah nanas (N5), dan kulit buah naga $250 \mathrm{~g}$ dan $250 \mathrm{~g}$ buah nanas

Keterangan: Nilai yang diikuti oleh huruf yang sama tidak berbeda nyata pada taraf uji BNJ 0,05

Gambar 2 menunjukkan bahwa kadar air selai terendah pada perlakuan N6 yaitu $18,65 \%$; sedangkan kadar air selai tertinggi pada perlakuan $\mathrm{N} 1$ yaitu $25,37 \%$. Hal ini menunjukkan bahwa semakin banyak kulit buah naga yang digunakan kadar airnya semakin tinggi. Menurut Hasrudin et al. (2017), kadar air kulit buah naga termasuk tinggi yaitu mencapai $75,58 \%$.

Kadar air selai kulit buah naga berdasarkan uji BNJ 5\% pada masingmasing perlakuan baik pada perlakuan N1 hingga N6 tidak berbeda nyata ini disebabkan oleh proses pemasakan yang menyebabkan kadar air selai akan mengalami penurunan selama proses pemanasan sehingga persentase kadar air tidak berbeda nyata secara signifikan. Walaupun tidak signifikan namun kadar air selai kulit buah naga telah memenuhi standar kadar air selai buah (SNI-01-37462008) yaitu maksimal 35\% (BSN, 2008).

\section{Kadar Gula Selai Kulit Buah Naga}

Kadar gula selai buah naga dari terendah hingga tertinggi yaitu N1 sebesar 42,65\%; N2 sebesar 47,4\%; N3 sebesar 48,7\%; N4 sebesar 50,4\%; N5 sebesar 51,75\%; dan N6 sebesar 53,30\% (Gambar 3). Menurut SNI-01-3746-2008 (BSN, 2008) mengenai syarat mutu selai buah, kandungan gula total selai minimal adalah 65\%. Menurut Turmala et al. (2013), kadar gula pada selai minimal $40 \%$ mampu menekan pertumbuhan kapang dan khamir sehingga dapat menghambat pertumbuhan mikroorganisme. Hal ini berarti bahwa selai kulit buah naga dengan penambahan buah nanas belum sesuai dengan standar kadar gula total selai namun sudah sesuai dengan standar minimal kadar gula dalam menghambat pertumbuhan mikroorganisme.

Pemakaian gula pada selai kulit buah naga pada penelitian ini sebanyak $200 \mathrm{~g}$ dikarenakan buah nanas turut berkontribusi dalam menambah rasa manis meskipun ada rasa asamnya juga. Menurut Irfandi (2005), gula yang terkandung dalam nanas yaitu glukosa 2,32\%; fruktosa $1,42 \%$; dan sukrosa $7,89 \%$. Hal ini menunjukkan bahwa penambahan buah nanas dapat meningkatkan rasa manis pada selai sehingga dapat mengurangi penggunaan gula dalam pemakaian. 


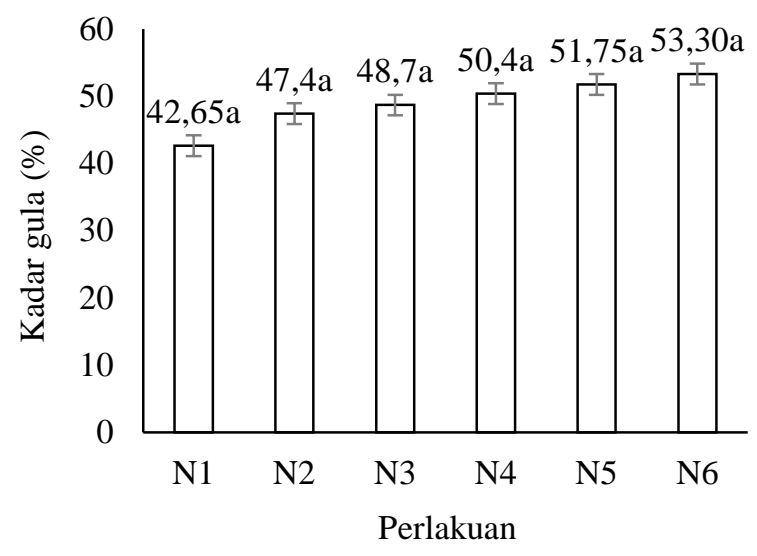

Gambar 3. Kadar gula selai kulit buah naga dengan penambahan buah nanas, dengan variasi kulit buah naga $500 \mathrm{~g}(\mathrm{~N} 1)$, kulit buah naga $450 \mathrm{~g}$ dan $50 \mathrm{~g}$ buah nanas (N2), kulit buah naga $400 \mathrm{~g}$ dan $100 \mathrm{~g}$ buah nanas (N3), kulit buah naga $350 \mathrm{~g}$ dan $150 \mathrm{~g}$ buah nanas (N4), kulit buah naga $300 \mathrm{~g}$ dan $200 \mathrm{~g}$ buah nanas (N5), dan kulit buah naga $250 \mathrm{~g}$ dan $250 \mathrm{~g}$ buah nanas

Keterangan: Nilai yang diikuti oleh huruf yang sama tidak berbeda nyata pada taraf uji BNJ 0,05

\section{pH Selai Kulit Buah Naga}

Salah satu faktor pada pangan yang memengaruhi pertumbuhan mikroba adalah pH. Gambar 4 menunjukkan bahwa derajat keasaman $(\mathrm{pH})$ selai berkisar antara 3,213,52. Nilai $\mathrm{pH}$ yang dihasilkan dari pencampuran kulit buah naga dan buah nanas tergolong dalam kondisi asam karena nilai $\mathrm{pH}$ berada di bawah 7 (normal).

Penambahan buah nanas pada selai kulit buah naga memengaruhi $\mathrm{pH}$ selai. Hal ini disebabkan oleh $\mathrm{pH}$ yang terkandung di dalam kulit buah naga lebih rendah yaitu 2,73-3,23 (Ingrath et al., 2015) dibandingkan dengan $\mathrm{pH}$ buah nanas yang berkisar 3,3-5,2 (US Food and Drug Administration, 2016). Menurut Fardiaz (1996), pH atau keasaman makanan dipengaruhi oleh asam yang terdapat pada bahan makanan secara alami. Nilai $\mathrm{pH}$ pada selai kulit buah naga dengan penambahan buah nanas sudah sesuai dengan standar yang menyatakan bahwa selai buah memiliki pH antara 3,5-4,5 (FDA, 2007).

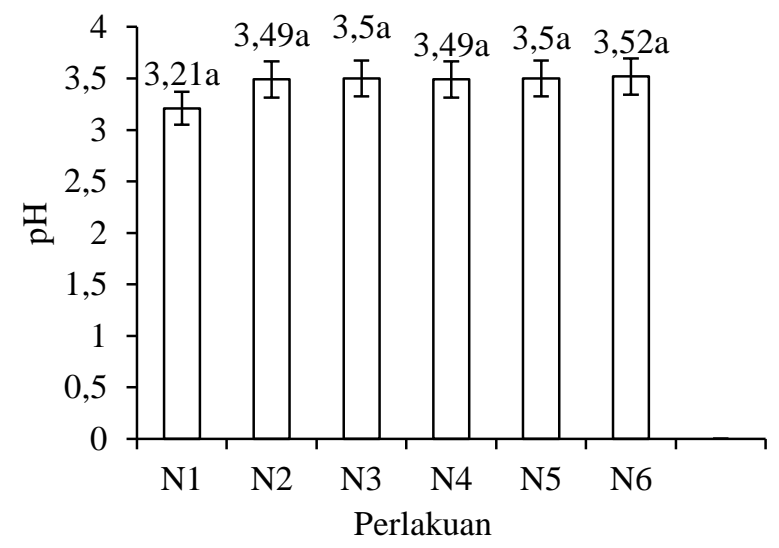

Gambar 4. pH selai kulit buah naga dengan penambahan buah nanas, dengan variasi kulit buah naga $500 \mathrm{~g}$ (N1), kulit buah naga $450 \mathrm{~g}$ dan $50 \mathrm{~g}$ buah nanas (N2), kulit buah naga $400 \mathrm{~g}$ dan $100 \mathrm{~g}$ buah nanas (N3), kulit buah naga $350 \mathrm{~g}$ dan $150 \mathrm{~g}$ buah nanas (N4), kulit buah naga $300 \mathrm{~g}$ dan $200 \mathrm{~g}$ buah nanas (N5), dan kulit buah naga $250 \mathrm{~g}$ dan $250 \mathrm{~g}$ buah nanas

Keterangan: Nilai yang diikuti oleh huruf yang sama tidak berbeda nyata pada taraf uji BNJ 0,05

\section{KESIMPULAN}

Selai kulit buah naga dapat dimodifikasi dengan penambahan buah nanas untuk meningkatkan karakteristik organoleptik sehingga menghasilkan produk yang lebih bernilai. Perlakuan N6 (selai dengan kulit buah naga $250 \mathrm{~g}$ dan 250 $\mathrm{g}$ buah nanas) merupakan kombinasi terbaik dalam karakteristik organoleptik terhadap rasa dan aroma yang dihasilkan meskipun tidak berbeda nyata dengan perlakuan lainnya. Meskipun N6 tidak memiliki tingkat kesukaan tertinggi terhadap tekstur dan warna, namun berdasarkan uji BNJ 5\% hasil yang diperoleh tidak berbeda nyata. Adapun karekteristik kimia (kadar air 18,65\%; pH 3,52; dan kadar gula 53,30\%) pada N6 yang diperoleh telah sesuai dengan standar SNI-01-3746-2008 dan Food and Drug Administration (FDA) 2007.

\section{UCAPAN TERIMA KASIH}

Terima kasih kepada pihak RISTEKDIKTI yang telah memberikan dana untuk penelitian ini melalui Hibah 
Penelitian Dosen Pemula Simlitabmas 2019/2020.

\section{DAFTAR PUSTAKA}

Arsyad, M. (2018). Pengaruh konsentrasi gula terhadap pembuatan selai kelapa muda (Cocos nucifera L). Gorontalo Agriculture Technology Journal, 1(2), $35-45$.

Badan Standarisasi Nasional (BSN). (2008). SNI-01-3746-2008: Syarat Mutu Selai Buah. Jakarta: BSN Indonesia.

Departemen Kesehatan RI. (1996). Daftar Komposisi Bahan Makanan. Jakarta: Bhatara.

Fardiaz, S. (1996). Strategi Riset Bidang Mikrobiologi untuk Meningkatkan Keamanan Pangan di Indonesia. Orasi Ilmiah Guru Besar Ilmu Mikrobiologi Pangan. Fakultas Teknologi Pertanian Institut Pertanian Bogor.

Food and Drug Administration (FDA). (2007). Approximate $p H$ of Foods and Food Products. USA: Center For Food Safety and Applied Nutrition (https://www.webpal.org/SAFE/aaareco very/2_food_storage/Processing/lacfphs.htm). [Diakses tanggal 13 Juli 2021].

Gultom, A.H., Herawati, N., \& Rossi, E. (2018). Penambahan kelopak bunga rosella dalam penambahan selai jambu biji merah. JOM UR, 5(2), 1-16.

Hardita, A.P., Yusa, N.M., \& Duniaji, A.S. (2016). Pengaruh rasio daging dan kulit buah naga merah (Hylocereus polyrhizus) terhadap karakteristik selai. Jurnal Ilmu dan Teknologi Pangan, 5(1), 14-25.

Hasrudin, S., Rostiati, \& Alam, N. (2017). Mutu kimia dan organoleptik pasta kulit buah naga (Hylocereus polyrhizus) hasil fermentasi dengan berbagai macam ragi. Agroland, 24(1), 57-63.

Herawati, N., Sukatiningsih, \& Windrati, W.S. (2012). Pembuatan minuman fungsional berbasis ekstrak kulit buah naga merah (Hylocereus polyrhizus), rosela (Hibiscus sabdariffa L.), dan buah salam (Syzygium polyanthum Wigh Walp). Jurnal Agroteknologi, 6(1), 40-50.
Herlina, H., Belgis, M., \& Wirantika, L. (2020). Karakteristik fisikokimia dan organoleptik fruit leather kenitu (Chrysophyllum cainitol) dengan penambahan CMC dan karagenan. Jurnal Agroteknologi, 14(2), 103-114.

Huriah, Nur, A., \& Noor, H.A. (2019). Karakteristik fisik, kimia, dan organoleptik selai pada berbagai rasio buah naga merah (Hylocereus polyrhizus Britt and Rose) gula pasir. Jurnal Pengolahan Pangan, 4(1), 16-25.

Ingrath, W., Nugroho, W.A., \& Yulianingsih, R. (2015). Ekstraksi pigmen antosianin dari kulit buah naga merah (Hylocereus costaricensis) sebagai pewarna alami makanan dengan menggunakan microwave. Jurnal Bioproses Komoditas Tropis, 3(3), 1-8.

Irfandi. (2005). Karakterisasi Morfologi Lima Populasi Nanas (Ananas comosus (L.) Merr.). Scientific Repository IPB University.

(http://repository.ipb.ac.id/handle/12345 6789/12566). [Diakses tanggal 13 Juli 2021].

Kumalasari, Ekafitri, R., \& Desnilasari, D. (2015). Pengaruh bahan penstabil dan perbandingan bubur buah terhadap mutu sari buah campuran pepaya nanas. Jurnal Hort, 25(3), 266-276.

Nizori, A., Sihombing, N., \& Surhaini. (2020). Karakteristik ekstrak kulit buah naga merah (Hylocereus polyrhizus) dengan penambahan berbagai kosentrasi asam sitrat sebagai pewarna alami makanan. Jurnal Teknologi Industri Pertanian, 30(2), 228-233.

Ramadhani, P.D., Setiani, B.E., \& Rizqiati, H. (2017). Kualitas selai alpukat (Persea americana Mill) dengan perisa berbagai pemanis alami. Jurnal Teknologi Pangan, 1(1), 8-15.

Santoso A.F., \& Fibrianto K. (2017). Pengaruh ekstrak kulit buah naga merah (Hylocereus polyrhizus) terhadap kualitas sosis ayam. Jurnal Pangan dan Agroindustri, 5(4), 92-96. 
Setyaningsih, D., Apriyanto, A., \& Maya, P.S. (2010). Analisis Sensori Pangan Untuk Industri Pangan dan Agro. Bogor: IPB Press.

Syaifuddin, U., Ridho, R., \& Harsanti, R.S. (2019). Pengaruh konsentrasi kulit buah naga merah dan gula terhadap karakteristik selai. Jurnal Teknologi Pangan dan Ilmu Pertanian (JIPANG), 1(1), 27-39.

Turmala, E., Hervelly, \& Wardhana, N.K. (2013). Kajian Pengaruh Konsentrasi Gula dan Konsentrasi Pektin Terhadap Karakteristik Selai Buah Campolay (Pouteria campechiana). Hasil Penelitian Fakultas Teknik Universitas Pasundan. Bandung.

Taiwan Food Industry Development and Research Authorities. (2005). Dragon Fruit. (http//swarnabhumi.com/dragonfruit/he alth_benefits_of_dragonfruit.htm). [Diakses tanggal 13 Juli 2021].

US Food and Drug Administration (2016). pH Values of Various Foods. (http://www.fda.gov/Food/FoodborneIll nessContaminants/CausesOfIllnessBad BugBook/ucm122561.htm). [Diakses tanggal 13 Juli 2021].

Utami, W., Mardawati, E., \& Putri, S.H. (2020). Pengujian aktivitas antioksidan kulit buah naga merah (Hylocereus polyrhizus) sebagai masker gel peel off. Jurnal Industri Pertanian, 2(1), 95-102.

Waysima, Adawiyah, \& Dede, R. (2010). Evaluasi Sensori (Cetakan ke-5). Bogor: Fakultas Teknologi Pertanian Institut Pertanian Bogor.

Winarno, F.G. (2004). Kimia Pangan dan Gizi. Jakarta: Gramedia Pustaka Utama.

Wu, L.C., Hsu, H.W., Chen, Y., Chiu, C.C., \& Ho, Y.I. (2006). Antioxidant and antiproliferative activities of red pitaya. Food Chemistry, 95, 319-327. 